\title{
Introduction to the special issue in honour of Wojciech Charemza
}

\author{
Stephen G. Hall • Dan Ladley
}

Published online: 13 May 2011

(C) Springer Science+Business Media, LLC. 2011

Wojciech Charemza obtained his masters degree in 1971 from the University of Gdansk, he then obtained his doctorate in economics in 1975 and his doctor habilitatus in 1981, both also from Gdansk where he was first a teaching assistant and eventually became an associate professor. In 1983 he moved to the UK first as a research fellow at the centre for Russian and East European Studies at University of Birmingham. Later, in 1987, he joined the University of Leicester, initially as a lecturer with a subsequent promotion to full professor in 1991. Wojciech has maintained close links with Poland, and Eastern Europe in general, holding a number of visiting or honorary appointments, including visiting the European University at St Petersburg, advising the Governor of the National Bank of Poland, being an honorary member of the scientific council of the Romanian Academy, visiting professor at the economics high school in Moscow and the University of Warsaw and in addition he has maintained a long involvement with the University of Gdansk, partly through a series of 6 European Community ACE grants which have funded a data centre at the University.

Wojciech's influence goes well beyond his academic CV however. For many years before the fall of the Soviet Union he was one of the main conduits of the many developments in time series econometrics into Eastern Europe. His work has had a profound influence on the development of econometrics in the whole region. This came about partly as a result of the many workshops and small conferences which he organised as part of the series of research projects which were based in Gdansk and partly as a result of his publications which were widely circulated across the region. Of particular note in this regard is his highly influential book 'New Directions in Econometric Practice: General to Specific modelling, Cointegration and Vector Autoregression' which was co-authored with D.F. Deadman. This book was very widely circulated in Eastern Europe and became, probably, the

S. G. Hall $(\bowtie) \cdot$ D. Ladley

Leicester, UK

e-mail: s.g.hall@le.ac.uk 
main source of information in the region regarding the new style of time series econometrics; it was even translated into Polish in 1997.

For many years Wojciech was the editor of the journal Economics of Planning which was renamed in 2005 as Economic Change and Restructuring to reflect the changing nature of the Eastern European economies. This special issue, which is in his honour, marks the special contribution which he has made to the journal and to developments in econometrics in the region.

Wojciech Charemza continues as a professor at the Department of Economics, we both hope to continue to have him as a colleague for many years to come. 